\title{
The Effect of Outdoor Study on the Geography Scientific Paper Writing Ability to Construct Student Character in Senior High School
}

\author{
Andri E. Sejati, La Ode Amaluddin, Desi N. Hidayati, \\ Sitti Kasmiati \\ Department of Geography \\ Universitas Halu Oleo \\ Kendari, Indonesia \\ anes_unes36@yahoo.com
}

\author{
Sumarmi, I Nyoman Ruja \\ Department of Geography \\ Universitas Negeri Malang \\ Malang, Indonesia
}

\begin{abstract}
Education and character are two important things related to each other. National curriculum includes the characters that need to be understood and implemented the Indonesian students. Teachers can build the students' character by using method that includes structured character activities. Scientific paper is a product that needs to be improved for the sake of implementing National curriculum. Students' characters can be observed from writing scientific paper. Outdoor study method can set out the students' characters through the steps of learning and scientific paper which becomes the final product. Outdoor activities can be conducted on Geography subjects because geographic objects exist in the world. The aim of this paper is to discuss the effect of outdoor study on the geography scientific paper writing ability to build the students' characters in senior high school. The research uses quasi experimental design with two groups, namely experimental class and control class. The analysis data uses independent sample t-test with SPSS 16.0. The research findings show that there is an effect of outdoor study on the geography scientific paper writing ability to build the students' characters with significant value of 0.00 . The effect can be seen in the scientific paper results and activities in the outdoor study step of learning such as: class preparation, area selection, group dynamics, equipment management in the field, outdoor work, return in the classroom, and student final report. Characters can be constructed are: honesty, discipline, responsibility, caring, politenes, environmental awareness, cooperative behaviour, responsiveness, and independence.
\end{abstract}

\section{Keywords-Character, Outdoor Study, Scientific Paper}

\section{INTRODUCTION}

Outdoor study is also called by various terms such as outdoor learning, outdoor activities, field learning, and learning outside the classroom. Outdoor study is an activity outside the classroom to make learning interesting and fun. It can be done anywhere with emphasis on the learning process based on the fact that learning materials are directly experienced. Reference [1], outside the classroom education is defined as education that goes outside the classroom involving experience.
Outdoor study has strengths and weaknesses. There are four types of strengths of the outdoor study related to scientific paper writing. Firstly, it uncovers the facts and obtains data by empirical observation in the field. In conducting outdoor study, teachers ask the students to visit places with certain geographic objects. Facts and data found in these objects are important parts of paper wariting on geography. Reference [2] scientific papers are produced primarily based on data and facts that they (students) have encountered in the field.

Secondly, outdoor study can encourage the student's motivation. Encouragement of learning motivation arises from directly interacting with geographical objects. This is due to something that does not contain in the book can be direcly observed in the field, so that it raises the student's curiosity. Curiosity encourages students to seek answers or work harder to complete the scientific paper. According [3], the advantage of environmental study in learning is more interesting. This can improve the students' motivation..

Thirdly, outdoor study makes into the students' learning more meaningful. Meaningful learning occurs when the students can understand the importance of science for the real life. Fourthly, outdoor study method is suitable to be applied on the Geography subject because the geographic material objects or geosphere phenomenon are available in the field. Learning experience and suitability of outdoor study on Geography subject make the students easily find the idea to be written in their scientific papers. Reference [3], that there are many advantages that be obtained from field study activity (particularly environmental study), one of which is the essence of learning that is more meaningful because the students are faced with the situation and the real condition. Reference [4], outdoor study can make the persons not be strange with their surrounding environments, and can direct their friendly attitude to the nature, and maintain its sustainability. Referene [3] states that for a geographer, a field work is a key component to understand the object. That is an important element in planning the geography curriculum with the base of outdoor activity and environmental education. 
There are two weaknesses of outdoor study. Firstly, the teacher finds it difficult in organizing learning process in the field. Secondly, this kind of learning needs much travel cost. To overcome the problems, it is necessary for the teacher to organize learning in the field in such a way that the students are motivated in their study. This can be conducted based on the organized activities completed with observation sheet, documentation, interview guides, tools, and schedule of activities. To overcome the problem in the travel cost, the teacher may determine the objects of field study not far from school. Reference [5] states that a planning plays an important role; without a good planning a field study is not better learning in the classroom.

In conducting a field study, the teacher may determine the steps for organizing the field study or outdoor learning. There are several steps. In general, outdoor learning steps are same as one and another. The researchers choose [6] as a reference guide. These are: class preparation, area selection, group dynamics, equipment management in the field, outdoor work, being back to the classroom, and students' final report. The other types of steps are stated in reference 7], including: preparation, implementation, and evaluation.

Scientific paper includes in the paper work which becomes an important product and should exist in the implementation of scientific approach in National curriculum. In Geography subject, there are some topics to produce a paper work, as those in XI grade in the matters of natural resources, population, and environtment preservation. This ability is important for students to participate in scientific writing competition. The champion certificates could improve the school name, school accreditation, and supplementary documents in National Selection of Students in State Higher Education (SNMPTN.)

The selected matter in research is the environment. Environment in this case is the zone karst hills of Kendeng near the school location. The locations selected as the objects are two areas representing damage and environmental preservation of karst hills so that the students can compare the good and bad efforts. The teacher can construct students' characters using the outdoor study method that contains structured character activities. Outdoor study method can construct students' character through the steps of learning and scientific paper into the final product. Students' characters can be observed from writing scientific paper. Good efforts on the environment can improve the environmental awareness character. Other characters also can arise when students apply outdoor study method as directed by the teacher. According to [8], one of efforts to handle human with low environmental awareness can conducted with guidance to the community (including students) through formal education.

\section{METHOD}

This research applied quantitative methodology with quasi experimental type. Quasi-experimental research design is nonequivalent control group design. It was chosen because it has two groups that were not selected randomly. Subjects in this research were students of grade XI IIS Senior High School
Muhammadiyah 1 Babat, Lamongan second semester of academic year 2015/2016, consisting of XI IIS 1 and XI IIS 2. The researcher set purposively XI IIS 1 as an experimental class and XI IIS 2 as class control based on the same abilities (geography final score of previous semester). Reference [9], states that in the nonequivalent control group design, the experimental group and control group are not chosen randomly.

Experimental class and control class get different application methods. The experimental class get treatment using outdoor study method (observation, interviews, and media map). The control class get the treatment using conventional methods (lectures, discussion, question and answer, and media images and maps).

The research instruments in this research are guidelines and assessment of scientific paper writing. The guidelines are to measure the effect of outdoor study method related to students' scientific paper quality. Paper work guidelines and assessment aspects are based on scientific writing competition of Senior High School level in UM XII Anniversary 2014. The weight of every assessment aspect, scoring, and criteria are based on the guidelines of students' creativity program 2014 to be modified.

The data collected in this research are primary and secondary data. The primary data is scientific paper writing ability on geography. Secondary data is a list of students' scores in the last semester and information about the school. Data collection in experimental and control classes was conducted by geography teacher of grade XI IIS Senior High School Muhammadiyah 1 Babat. The researcher conducted observation, and prepared lesson plans and research instruments. Data collection was carried out for six weeks.

The analysis data used parametric inferential statistics, including test precondition analysis and hypothesis test. Test precondition analysis consists of normality and homogeneity tests. Normality test used to determine whether the gain score is normally distributed or not, using one-sample Kolmogorov Smilnrov with SPSS 16.0 for Windows at significance level of 0.05 . Homogeneity test used to determine whether the gain score is homogeneous or not, using Levene's test with SPSS 16.0 for Windows at significance level of 0.05 . The hypothesis test used the independent sample t-test with SPSS 16.0 for Windows at significance level of 0.05 .

\section{FINDINGS AND DISCUSSION}

\section{A. Findings}

The test precondition analysis result shows that the gain score is normal distributed with significance value $=0.183$ in experimental class and 0.924 in control class. The gain score is also homogeneous with significant value $=0.143$. This result means that the gain score qualifies to analyze with parametric inferential statistics. The research results show that the significant value is 0.000 . The significance value $<0.05$ so that $\mathrm{HO}$ is rejected. The research results indicate that there was an effect of outdoor study method on the students' scientific paper writing ability. The initial and final data about students' 
scientific paper writing ability in experimental class and control class can be seen in Table 1 .

TABLE I. THE STUDENT EARLY AND FINAL SCIENTIFIC PAPER WRITING ABILITY

\begin{tabular}{|c|c|c|c|c|c|c|c|c|c|}
\hline \multirow[t]{3}{*}{ Criteria } & \multirow{3}{*}{$\begin{array}{l}\text { Score } \\
\text { Range }\end{array}$} & \multicolumn{4}{|c|}{ Control Class } & \multicolumn{4}{|c|}{ Experimental Class } \\
\hline & & \multicolumn{2}{|c|}{ Early } & \multicolumn{2}{|c|}{ Final } & \multicolumn{2}{|c|}{ Early } & \multicolumn{2}{|c|}{ Final } \\
\hline & & $\mathbf{f}$ & $\%$ & f & $\%$ & $f$ & $\%$ & f & $\%$ \\
\hline $\mathrm{Bad}$ & $0-100$ & 0 & 0 & 0 & 0 & 0 & 0 & 0 & 0 \\
\hline Very Less & 101-200 & 0 & 0 & 0 & 0 & 0 & 0 & 0 & 0 \\
\hline Less & $201-300$ & 9 & 25 & 4 & 11 & 11 & 31 & 0 & 0 \\
\hline Enough & $301-400$ & 21 & 58 & 23 & 64 & 20 & 57 & 0 & 0 \\
\hline Good & $401-500$ & 6 & 17 & 99 & 25 & 4 & 12 & 29 & 83 \\
\hline Very Good & $501-600$ & 0 & 0 & 0 & 0 & 0 & 0 & 6 & 17 \\
\hline Perfect & $601-700$ & 0 & 0 & 0 & 0 & 0 & 0 & 0 & 0 \\
\hline \multicolumn{2}{|c|}{ Total } & 36 & 100 & 36 & 100 & 35 & 100 & 35 & 100 \\
\hline
\end{tabular}

Table I shows that the final data in the experimental class spread out on good and very good criteria. Students in experimental class do not get the scores in less and fair criteria as those in their initial ability. Final data of control class are distributed into less, fair, and good criteria. Students in control class get the scores in less criteria although the amount reduce (5 students). There were still many students in control class who remain in fair criteria (23 students), and those who are in good criteria increased ( 3 students). The final scientific paper writing ability results in control class is almost the same as the initial one. The data distribution indicates that there are differences between experimental and control class.

From the observation data and explanations above it can be concluded that the student scientific paper writing ability in experimental class is higher than control class. The average early scientific paper writing ability, control class and experimental class have almost the same scores, even control class is better than experimental class. Final scientific paper writing ability results show the opposite, that is experimental class is better than control class. This indicates that the use outdoor study method has better effect on the students' scientific paper writing ability.

The outdoor study learning method can be well followed by the students. Learning process is in accordance with the of the outdoor study. Students receive guidance from teachers at every step through the provided instruments. Each step gets good response from the students, especially in the step of outdoor work. Students are glas to conduct observations and interviews in the field. In the control class, learning activities are dominated by the use of books and the internet. This only give a little effect on scientific paper writing.

Characters covered in competency standard of National curriculum, are: honesty, discipline, responsibility, care, politeness, environmental awareness, mutual cooperation, cooperation, peace-love, responsiveness, pro-active attitude, and independence. Characters constructed during the implementation of the outdoor study, include: honesty, discipline, responsibility, care, politeness, environment awareness, cooperative behaviour, responsiveness, and independence. This shows that the outdoor study covers $75 \%$ of the characters in the basic competence. These characters are seen while following learning stages and students' scientific paper. The implementation of the method which can embed the characters can construct the good students' characters permanently.

\section{B. Discussion}

\section{1) The Effect of Outdoor Study on the Geography Scientific Paper Writing Ability}

Outdor study method has a significant effect on the students' scientific paper writing ability. It is also reflected in the learning steps during the time of research. Each step links to students' scientific paper writing ability. The first step is class preparation, in which the students' activities are prepared to study or understand the material, the instruments, and the use of the equipments by themselves. Students also begen to plan how to communicate the report (scientific papers). All activities aim to make students able to analyze the damage, preservation, and environmental preservation solutions on karst hills in the form of scientific papers. Students also learn the list of activities during outdoor study. Reference [7], in planning the field study it is necessary to consider what the product that will be made and what experience that will be obtained by the students.

The scientific paper is product made by students. Initial planning is meant to make students more systematic in writing scientific paper. Second, the step of area selection is meant to make students know the location that will be observed. Students understand the focus that will be observed (physical and social environments). The physical condition is integrity form and uniqueness of karst hills observed directly by students. Social condition is the human action on karst hills, done by whom, and what the motive. Both of these are well understood by students. The scientific papers produced by them contain location and physical and social aspects of the research object/subject. Reference [7] stated that the object of study on geography is about earth surface and all processes happened and the influence or human interaction factor.

The third step is to make group dynamics. The students are divided independently. They are led by class chairman to be divided into small groups for collecting data (interview). Group dynamics functions to make data collection (interview) more effective. Group work also continue in discussion session after outdoor work to process the data. The results of data processing are described individually in each scientific paper.

The fourth step is equipment management in the field. The students understand and practice using the instruments that will be used. Students understand the meaning of the questions in the interview guides and do exercises with friends of their group using the Java language. The second activity will be defined, prepared, and practiced using the equipments used ( $\mathrm{HCl}$, pipettes, and cameras). The fourth step is to make students understand more about the research method reflected in their scientific paper. Students also use the test result on karst rock in part of literature study. The second part (method and literature study) achieves the largest increase in the second and third positions with 30.57 and 25.28 point.

The fifth step of outdoor work is that students collect the data and observe the facts on the field. They collect the data 
through interview and observation. When observing, at the same, they conduct the test on karst rock. The observation on the hill is directly conducted. In the process of observation, they also take the picture of the hill. Each group interviews to one miner and one community (village head, village elders, sellers, and people around the hill) at the second location. Observation and interview take 1.5 hours.

The sixth step of the field study is that the students come back to the classroom and then they make final report. They make scientific paper related to environmental damage and preservation of karst hills. Their activities in this step starts from processing the data and formulating research methods from what they have experienced. They present the results of the field study in scientific paper, combined with knowledge they obtained in the classroom. In this step, they pass through two meaningful learning dimensions, that are: inputing the knowledge gained by themselves under teacher's guidance, and linking it to existing knowledge. Reference [10] states that the meaningful learning is a process of tying new information on the concepts relevant to a person's cognitive structure. Reference [11] states that the learning process outside the classroom can provide direct experience so that lesson is more concrete and real. It means that learning activities are more meaningful.

Teacher's duty is to give assistance and at the same time to observe the students' activities in the paper writing process. The results of the whole steps show are said to get better. Facts and data are presented in the students' academic paper from introduction, literature study, and to the results and discussion. The fourth section proves the highest increase in experimental class.

\section{2) The Effect of Outdoor Study on the Scientific Paper Writing Ability on Geography to Construct Students' Character}

The characters are improving better while attending the steps of learning during the outdoor study and scientific paper writing. These are: honesty, discipline, responsibility, care, politeness, environment awareness, cooperative behaviour, responsiveness, and independence. Honest is reflected in the step of outdoor work, when the students collect data. In data collecting, they are not fully supervised by teachers. The teachers just give a guidance and directed and they do not participate in the activities of interviews. In the efforts to control and to save time, the teachers divide the students into small groups. Reference [7] states that the number of members in each group must be considered to determine the effectiveness of the data that should be collected.

Character of discipline is reflected in submitting the students' scietific papers. They submit their papers in accordance with the determined time. They have high spirits to complete their scientific papers as final reports. The students' interest affects their performance in completing the scientific papers. The process of completing those papers becomes more organized as the effort to reach the target. Reference [12] states that PjBL including field study makes the students' performance in completing scientific paper more organized.
Reference [13] states that the physical, mental, and emotional involvement encourages the willingness, ability, high curiosity, and at the same, functions as the effort to improve quality of learning outcomes.

Character of responsibility can seen when a group of students present and defend the findings of field study as written in their scientific papers to another one. Students are responsible in the academic processes: collecting data and relating the data to their knowledge. In answering the questions from other group, the students show their responsibility. Reference [5] states that the students' learning activities are more comprehensive and active when conducted through the outdoor study because it can be done in various ways. One of which is prove and test the facts that have been processed.

Care is one of the characters arising from students to directly see the problems in the mining of karst hills. The charater of care is reflected in scientific paper on geography in the form of solutions related to miners' welfare. Mining occurs because people do not other alternative jobs. The students propose solutions to resolve the problem, that the government should provide jobs for the miners. This shows that the outdoor study can improve students' social sensitivity level while observing the human element in the object of field study. Reference [14] states that outdoor study can be an effective method in helping the overall students' development, including: physical-motoric, socio-emotional and cultural, and intellectual development.

Courtesy is an important character to be built in Indonesia. Indonesian people are known to be polite by the international community. Students' courtesy is reflected when they conducted the interviews with the miners and also conservationists as the effort to collect data and facts in the field study. Each group interviews one miner and one conservationist om the karst hills. The use of the "krama inggil in Javanese language" shows the good manner in communication and interaction to the older people. Reference [12] states that students collect data from the field through observations and interviews with good manners can make their scientific paper better.

Observations and interviews in the field made the students more aware of the surrounding environment. It can improve the character of environment awareness. This character is reflected in the students' scientific paper in the form of explanation on the environmental damage. They state that the environmental destruction should be avoided. Activity of conservation as a good behavior should be continually maintained. Preservative solution implies behavior of environmental awareness, such as: tightening the permits of karst mining, planting fast-growing trees, expanding green areas, making the guarding team of green hills, and determining penalties for hill destroyers. Reference [15] states that the outdoor study makes students more familiar with the environment. Reference [9] states that one of the ways to control environmental damage is by ethiques determined for maintaining the environment. The ethiques are expected to have good impact for building the community's (including students') characters. 
Character of cooperation is reflected when the students work in groups to collect, process, and present the data. They work in small groups to accomplish their duties together. Teachers can assess whether or not the students work in groups based on their compactness during the process of field study. Compactness also can be assessed by the group coordinator by noting them as passive members. Reference [5] states that the students' learning activities through the outdoor study are more comprehensive and active due to their group working.

Responsiveness expreses a thought to respond problems quickly. This responsiveness is reflected in the students' academic writing, that the ex-mining area is proposed to be a tourism determination area. This can be said an effort to stop the damage and increase the welfare of the local population. This is based on the reason that the rest of the hill due to mining activities form a beautiful cliff. The students' idea shows their response toward miners who still operate without permit due to not having a job. The tourist determination area can be made by the ex-miners as for the trading area. Here, they can sell food, drinks, and other merchandise.

Independence character can be seen from all the outdoor study steps. Teachers act as a motivator and facilitator. Students work independently in collecting data and making scientific paper. Observations are also independently conducted; the teachers just give motivation and guidance during observations. During the interview, the students are given the interview guidelines. Observation and interview guidelines function as the students' working indicator, so that the teachers do not need to monitor one by one. Reference [16] states that the application of outdoor study implies that the teachers are not necessary to monitor too much due to all the students work independently in groups.

\section{CONCLUSIONS AND SUGGESTIONS}

\section{A. Conclusions}

The result of research shows that there is an effect of the outdoor study in building the students' characters as reflected in the steps of the field study and in the students' scientific papers on geography in senior high school with significance value of 0.00 . Characters reflected are: honesty, discipline, responsibility, care, politeness, environmental awareness, cooperative behaviour, responsiveness, and independence. The teacher can build the students' characters through the outdoor study based on the structured character building activities.

\section{B. Suggestion}

When a teacher will conduct an outdoor study as an alternative method to train the students in writing scientific papers, it is suggested to set up an instrument as a controlling means for the students' activities in the field. The instrument covers the schedule of outdoor study, equipment (including cameras), and interview guides. Interview guidelines is suggested to developed by the teacher based on the problems in location of the field study. This instrument is useful as controlling means for the students' activities.

\section{REFERENCES}

[1] Husamah, Pembelajaran Luar Kelas (Outdoor Learning), Jakarta: Prestasi Pustakarya, 2013.

[2] A. Amirudin, A. Fatchan dan S. , Pengembangan Pembelajaran Kontekstual Melalui Outdoor Study untuk Meningkatkan Aktivitas dan Kemampuan Menulis Karya Ilmiah Siswa Pada Materi Geografi, Unpublished, 2009.

[3] N. Sudjana dan A. Rival, Media Pengajaran, Bandung: Sinar Baru Algensindo, 2010.

[4] A. Vera, Metode Mengajar Anak di Luar Kelas (Outdoor Study), Jogjakarta: DIVA Press, 2012.

[5] H. Bilton, Outdoor Learning in the Early Years, London and New York: Rouledge Taylor and Francis Group, 2010.

[6] Sumarmi, Model-Model Pembelajaran Geograffi, Malang: Aditya Media Publishing, 2012.

[7] Abdurrahman, Belajar dan Pembelajaran, Bandung: Alfabet, 1995.

[8] Sumarmi dan A. Amirudin, Geografi Lingkungan Berbasis earifan Lokal, Malang: FIS-UM, bekerjasama dengan Aditya Media Publishing, 2014.

[9] Sugiyono, Metode Penelitian Kuantitatif dan Kualitatif, Bandung: Alfabeta, 2010.

[10] R. W. Dahar, Teori-Teori Belajar dan Pembelajaran, Bandung: Erlangga, 2011.

[11] S. P. Prasetya, Media Pembelajaran Geografi, Yogyakarta: Penerbit Ombak, 2014

[12] A. Baidowi, "Pengaruh model pembelajaran berbasis proyek terhaddap kemampuan menulis karya ilmiah geografi siswa SMA,” Jurnal Pendidikan Geografi , vol. 20, pp. 48-58, 2015.

[13] H. D. Nugroho, Strategi Pembelajaran Geografi, Yogyakarta: Penerbit Ombak, 2013

[14] R. Mariana, Strategi Pengelolaan Lingkungan Belajar di Taman Kanak-Kanak, Jakarta: Depdiknas-Ditjen, Dikti-Direktorat Pembinaan Pendidikan Tenaga Kependidikan dan Ketenagakerhaan Perguruan Tinggi, 2005.

[15] K. Paisley, N. Furman, J. Sibthorp dan J. Gookin, "Student learning in outdoor education: a case study from the national outdoor leadership school," Journal of Experimental Education, vol. 30, pp. 201-222, 2008

[16] Harini, I. D. Kartika, A. Fatchan, S. Utaya dan A. Amirudin, "Pengaruh pembelajaran tugas kelompok berdasarkan survei lapangan (outdoor study) terhadap kemampuan menulis karya ilmiah dan hasil belajar siswa," Jurnal Penelitian Pendidikan Lemlit-UM, vol. 22, pp. 12-21, 2012. 